\title{
Research on the Occupation Career Planning of Cadets
}

\author{
Yanbin Shi \\ Aviation University of Air force \\ Changchun, 130022, China \\ xiaoshi_80@163.com \\ Guangyu Wang \\ Aviation University of Air force \\ Changchun, 130022, China \\ 1803097835@qq.com
}

\author{
Lijuan Pan \\ Changchun Xiwang Middle School \\ Changchun, 130022, China \\ cherry_0114@163.com \\ Changchun Deng \\ Aviation University of Air force \\ Changchun, 130022, China \\ 1241238363@qq.com
}

\begin{abstract}
The aim of this study was to construct the occupation develop route, and to help individual cadet to find out and assess internal and external quality of environment, realize the self-value effectively. On the background of officer professionalism, the work presented in this paper focuses on several aspects of the occupation career planning of the cadets. It is analyzed of the occupation career theory, occupation career planning and managing theory, and the professional commitment theory adapt to the cadets, the content and necessity of occupation career planning. The problem is within the scope of the theoretical foundation and frame designing for occupation career planning. These theories suggest that the occupation career planning should develop at the beginning of the serve.
\end{abstract}

Keywords-Occupation Career Planning; Cadet; Professionalism

\section{INTRODUCTION}

The president $\mathrm{Xi}$ point out, aiming at set up Chinese characteristics officer's professional system, catching the key questions such as officer's management, qualifications on active service, categorized, etc., set up all kinds of talents scientifically and grow up routes, make great efforts to realize the break-through in the important field and key links. As officer's professionalism color of China military shows strongly, it is necessary for the military universities and colleges to launch the occupation career planning education to the cadets of military universities and colleges, respecting the needs of personal development of cadets, according to officer's job characteristic and rule of development guiding cadets, strengthens subject consciousness, defines the objective of the struggle, trains one's own military key abilities consciously, offers the chance of sustainable development, helps them to realize the personal goals and gets ready to meet the military work under the environment of military development better in future, makes their career have more intact continuity and development.
This paper is supported by the "13th Five-Year" planned subject on educational science of Jilin Province (GH16620).

\section{OCCUPATION CAREER PLANNING AND OFFICER'S PROFESSIONALISM}

Occupation career planning is the process of creating an action plan based on awareness, values, reflection, goal-setting and planning for personal development within the context of a career, education, relationship or for self-improvement [1]. It combines with individuals and organizations together, through determining, analyzing and summarizing the subjective and objective conditions of a person's career occupation, confirms its best job objective of the struggle, and make sure the effectual arrangement in order to realize goal. Include choosing the job which can realizes this goal, and make corresponding study, training and education plan. Arrange and establish the phased and long-term occupation goal and confirm that suits oneself development routes and method according to the regular tempo, define the adjustment that will be carried on and several plan, adopts the course that the essential action realizes the goal of one's own career. The purpose of occupation career planning is to let the subject consider the livelihood of all one's own life, make the choice, in order to bring one's own potentiality, energy to play. Undertaking of a satisfied, very challenging and self-actualization, create the greatest value by oneself too for the society. To be simple, through the occupation career planning, choose the occupation routes; realize the value of one's own life.

The occupation career planning is divided the personal occupation career planning and the organization occupation career planning. The personal occupation career planning is according to the demand of the society, combine one's own natural endowments, confirm the job goal, choose the route, and makes the detailed action scheme of studying, working, training etc. in order to realize the goal of career. The organization occupation career planning is in order to realize organizing the goal and personal job development goal to be unified (win-win) course, according to one's own development goal, accord with the staff's development demand, make and organize the demand strategy of the job, position change to plan with the job passway, and then take the requisite measure to implement. 
The officer's professionalism is the inevitable result of the social productivity and science technology developed into industrialization and informationation age, and at same time, it is the inevitable choice of the institutional framework military technology, the division among specialized departments developing into certain stage. Its essence is with the purpose of improving specialization intensity of officer's team, strengthening and finishing military task effectiveness, regular system of the job of constructing a whole set of officers. This paper use the definition of Zhang ChaoJin to officer's professionalism development plan, means that the army organizes and engaged in designing, carrying out, assessing, feed backing the management with revision in military job officer individual.

So, the occupation career planning is not a simple concept, it has close relationship with family and social. Everybody want to realize one's own social value and personal value to the maximum extent, he should complete his own occupation career planning well, especially for cadets on service. At the professional exploration stage, this planning has very important meaning to their job development in future exploration stage.

\section{THE THEORETICAL FOUNDATION OF OCCUPATION CAREER PLANNING}

The occupation career theory is the new stage of the human resources management theory has gone through the contemporary age science management theory, modern behavioral management theory and modern age science management theory [2]. It has already become developing direction and inexorable trend of present manpower resources management.

The centre content of the occupation career theory is the occupation career planning and managing [3], the purpose is to match suitable for the personnel engaged in particular job or position, help person to design and obtain and most suitable for career goal and development opportunity that its development grow up, bring into full play each one's ability, make the best possible use of talent. Its characteristic mainly includes:

\section{A. People-oriented}

People oriented means regard people's development as the core, mostly depend on personal self- guidance, self-control and comply with the human nature and pursue human-oriented management in managing actually actively.

\section{B. Pursue "win-win"}

Pursue "win-win" means through interdynamic between organization and personal, while realizing organizing the goal, promote personal and overall development.

\section{Dynamic management}

Dynamic management means according to different develop stages and different missions, combine the personal characteristic, development goal and develop difference of focal points, adopt different management, implement the course of the dynamic management.
Demand levels theory. The demand levels theory of the famous psychologist Maslow think, after people get the satisfaction such as respecting, safety, seek knowledge and beautiful, until reaching the satisfaction of the selfactualization. In now time, the young cadets who accept higher education demonstrate more high-level pursuit, therefore the self-actualization becomes the supreme goal that they pursue at work. So, when a person has his own imaginations about his occupation career development. When he finishes his own career according to his imaginations, he will have very high fulfillment and satisfaction, thus it will stimulate him and work more effectively. When the cadet will be enlisted in the armed forces and at the beginning of servers, according to officer professional characteristics and development rules, combining with the need of the organization to design his own occupation career, and create flexibility and creativity at his own professionalism posts has already been an extremely important issue [4].

Why begin the occupation career planning from cadets is that everyone hopes the occupation career planning can give play to one's own latent energy to the maximum extent during his whole own career, realize the self-value effectively, thus guarantee to make greater achievement in future. The aiming of the occupation career planning is to help individual finds out about oneself is correct to assess internal and external quality of environment, restrain from, etc. really not merely, what is more important thing is to assist individuals to reach the phased goal in life, and at same time realize the phased achievement of organization's.

The professional commitment refers the psychological connection between the individual and his occupation. That is a measurement of unwilling to change occupation because the individual approval and emotional beggar to his occupation. It also is a tolerance of the individual attitude to his occupation. In a way, it is a promise of individual bears to the certain professional responsibility; it is "psychological contract" between the individual and his occupation. Because it reflects the psychological connection between the individual and his occupation, so it can be used to predict steadily the absence and dimission behaviors. Liu [5] studied the occupational psychology of the defense students based on professional commitment.

\section{THE NECESSITY OF OCCUPATION CAREER PLANNING TO THE CADETS}

\section{A. It is the inevitable choice of professionalism development}

Though most people in the army think that the occupation career planning totally is a personal issue, but, in Hi-Tech world of now, people gradually find with changes such as technological informationization, economic globalization, workforce's diversification and pressure of the equal employment opportunity in the social development, etc. How to do need of balanced organizations and individuals seems more and more important and urgent [6]. The reform in army's personnel system, the renewal of technology, promotion of the position in market economy, officers want to make one's own latent energy get the greatest strong hope that give play to in their careers, impel and will inevitably participate in the design 
of cadet's career of military college to organize and to the management. So, organizations and individuals all will find gradually, the occupation career planning should be regarded as attempting to be satisfied with the cadets' individual and organization's interdynamic course need organization will pay attention to making the development plan of suitable job together with officers more and more.

Usually, the ideal state of the occupation career planning for cadets is designed by the cadets, management organization and political office together. Through construct occupation develop system, which can not only reflect the organization's goal and culture, but also reflect the cadet's develop direction.

Nowadays the society is full of competitions, fast-moving society, and at same time, it is emphasizing individual character, paying attention to the human nature. Military universities and colleges training cadet [7-8]. On the one hand, it uses scientific, effective method suitable human nature to help cadets choose and select correct developing direction and goal, develop latent energy. Thus the organization can be a fast and high-efficient fight team, promote the whole construction of the team. On the other hand, the organization should respect their individual demands, adjust the structure of military talents rationally, offer the developing chance to them, help them to realize the personal goal and get ready to adapt to the society better in future, make their career have a more intact continuity and development.

\section{B. It is the objective demand for individual development}

The occupation career planning helps cadets to coordinate the contradictions between the army and personal demands. According to actual conditions, to be an officer, that means the personal will will be limited in many aspects. After many cadets enlisted in the military colleges, he will find one's own interest, hobby, ability advantage are not fit for the specialty or post engaged in by oneself, in addition the mechanism that the existing talents of army flow rationally still treats complete, in this way the contradiction conflicts of the personal will incident and army's goal task, cause individuals to be difficult and publish the achievement, the country has wasted certain education and national defense funds too. So help them to carry on the career to plan to help the cadets of military school to find one's own best localization accurately, coordinate the contradiction between the personal and military demands, and make the personal development get more abundant exploration.

The occupation career planning favorites the development of individual character and improve the overall qualities. Because the occupation career planning is a kind of life-long education. So it is based on quality-oriented education. And quality-oriented education demands to respect the individual character, acknowledge personal interest and variety and difference of the ambition, unless develop the activity of education, excavate fully its latent energy, it makes every cadet unable to act on one's own, study lively, promote cadets to develop in an all-round way. So, the occupation career planning can develop cadet's perfect individual character, train the initiative spirit, benefit and combine development and social demand of individual character with again. Plan through the career, can make them know oneself, know the society more reasonably, make one's own personality improve constantly, seek the development of oneself, meet the demand of the social development, realize personal value finally.

\section{GLOBAL DESIGN OF THE OCCUPATION CAREER PLANNING}

The content of the occupation career planning is extensive, it involves every aspect of development in life, and mainly there are four aspects. Firstly, learn how to live. Let oneself become the social person from a natural person, looks after one's own life, but does not rely on others; learn to participates in social activities, become an effective citizen. Secondly, learn how to study: Utilize daily education and working to find and develop own latent energy, promote knowledge while being daily, improve and solve the problem, create and criticize the ability to think; Not only acquires knowledge, but also gets the key which open the repository, the method to learn self-study. Thirdly, learn how to making life. Not only to learn has a specialty in order to making life, but also grasp various modern civilized survived skills. Lastly, learn how to get along with people, begin with self-awareness and know people, and then love himself, love others, help himself and help others. The self-perfection in the career and realizing, promote the harmonious interpersonal relationships, thus found a meaningful career. The occupation career planning is not only a simple imparting knowledge process, but also relevant explore and practice activity based on the pursuit to life and career quality perform

So, during the course of the design and arrangement of the occupation career planning to cadets. Firstly, it should to emphasize the integration of experience. Elaborately choose the successful officers, research them success experience how to combine various knowledge, skill, attitude, habit obtained by army, society, officers, etc, and servers to the occupation career planning. Secondly, it should to emphasis on creating goal, the goals are the spiritual prop burning and the motive power of the life.

The goal must be realized by certain professional role in life, so in order to giving play to personal latent energy to the maximum, and learn to the new knowledge's constantly. For this long-range goal, people can stand the hard and setback in working and daily life. And at the same time, it should be emphasized the job meaning and sense of identity. The occupation career is the carriers of life career, the working is core of the life. Through the occupation career planning, to help cadets to understand the meaning and value, going all out with all heart, positive participate in and does not dodge without shrinking back in the face of the emergency rescues and disaster relief work.

\section{CONCLUSION}

In fact, the occupation career planning educational is a kind of training for ability, in other word, that is the training for people's survival ability. There are two important links can't be ignored, first one is educator, the individual inner world is a precondition of development of career. The second one is the relationship between individuals and social environment, look for appropriate position in the society. 


\section{REFERENCES}

[1] L. Chu, "The Path of College Students' Career Planning Education in the We-media Area", Journal of Hubei Correspondence University, Vol. 29: 17, pp. 22-23, Sep. 2016. (In Chinese)

[2] F. Jian, "On the Application of Knowledge Management Theory in College Student Occupation Career Planning", Journal of Xinyang Agriculture and Forestry University, Vol. 26: 2, pp. 158-160, Sep. 2016. (In Chinese)

[3] K. Chunmei, D. Jianwei, "A Comment on the Foreign Professional Career Development Theory", Journal of Inner Mongolia Finance and Economics College, Vol. 9: 3, pp. 5-9, Mar. 2011. (In Chinese)

[4] X. Wen, "Measures for Colleges in Helping Teachers Developing the Occupation Career Planning". Journal of Zhengzhou Institute of
Aeronautical Industry Management, Vol. 26: 2, pp. 116-118, Apr. 2008. (In Chinese)

[5] L. Aihua, "The study of current situation of occupational psychology of the defense students based on career commitment", Huazhong University of Science and Technology, May. 2007. (In Chinese)

[6] G. jun, "About the Career Planning Education for the Cadets", Journal of Higher Education Research, Vol. 35: 1, pp. 113-115, Mar. 2012. (In Chinese)

[7] F. Wei, "Analysis of Career Planning Education for the Soldiers Graduated from College", Journal of Anhui Vocational College of Police officers, Vol. 9: 51, pp. 68-71, Jun. 2010. (In Chinese)

[8] G. Hongbao, D Xiao-yu, "Analysis of Military Students Vocational Programme", Journal of Xia'n University of Arts and Science(Social Sciences Edition), Vol.10: 3, pp. 98-100, Aug. 2007. (In Chinese) 